\title{
A haemorrhagic cholecystitis presenting as obstructive jaundice
}

\author{
Xin Chen, Liangliang Yu \\ Department of Gastroenterology, Sir Run Run Shaw Hospital, Zhejiang University School of Medicine, Hangzhou, China \\ Correspondence to: Liangliang Yu, PhD. Department of Gastroenterology, Sir Run Run Shaw Hospital, Zhejiang University School of Medicine, No.3 \\ East Qingchun Road, Hangzhou, China. Email: yudanyu@zju.edu.cn.
}

Submitted Oct 04, 2020. Accepted for publication Oct 28, 2020.

doi: 10.21037/hbsn-20-737

View this article at: http://dx.doi.org/10.21037/hbsn-20-737
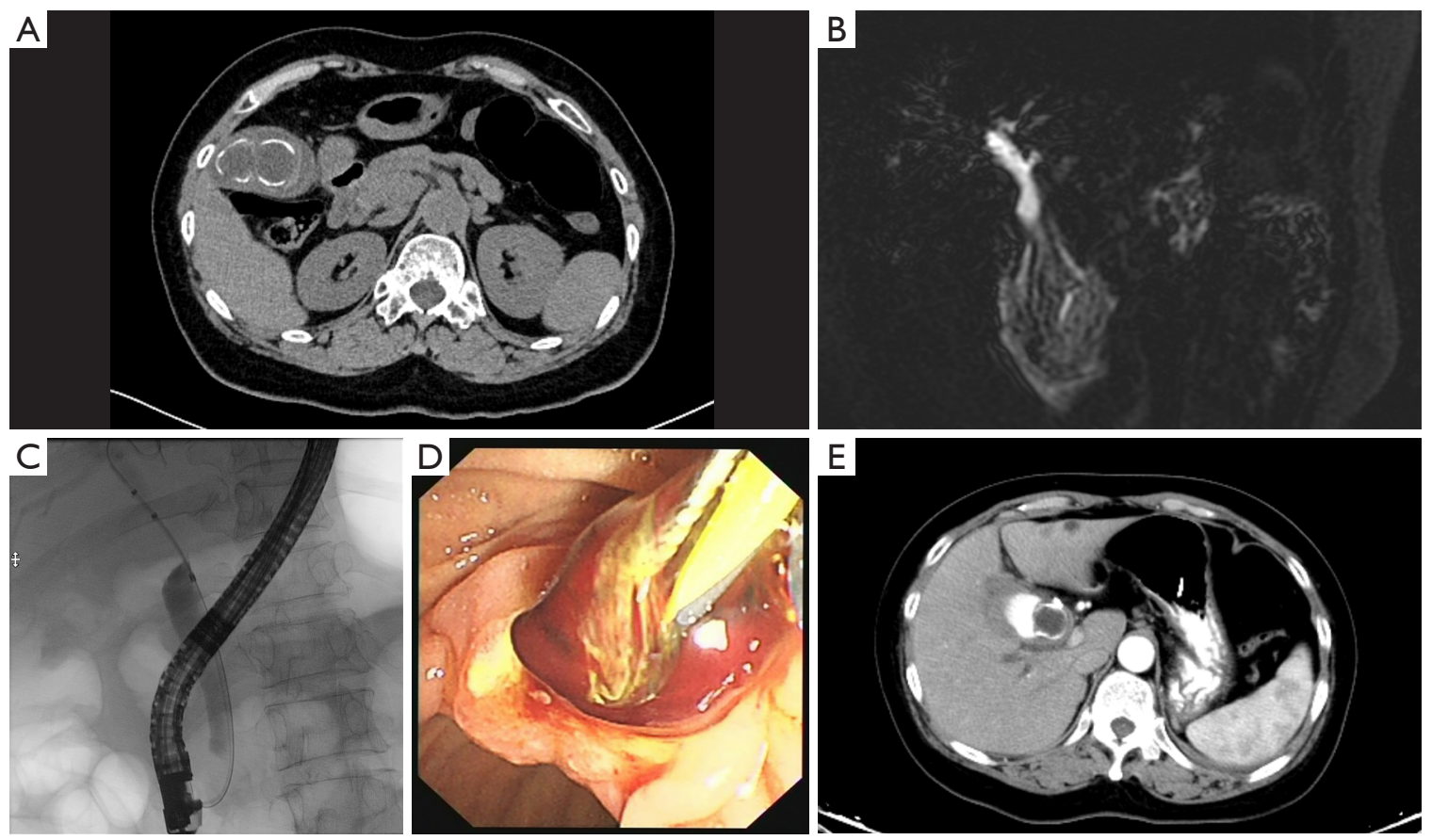

A 63-year-old female suffered right upper quadrant pain for 5 days, and icteric sclera for 3 days. Her Laboratory examinations revealed a normal blood routine and abnormal bilirubin levels: total bilirubin $222.0 \mu \mathrm{mol} / \mathrm{L}$, direct bilirubin $131.8 \mu \mathrm{mol} / \mathrm{L}$. Stool occult blood was negative. Abdomen/pelvis CT (Panel A) and MRCP (Panel B) showed cholecystolithiasis and lower choledocholithiasis.

In endoscopic retrograde cholangiopancreatography (ERCP), a large filling-defect was found blocking the common bile duct (Panel C). A dark red clot was taken out with reticular basket (Panel D), following by flow of blood. The bleeding stopped spontaneously soon. An endoscopic nasobiliary drainage (ENBD) was performed.
The day after ERCP, dull-red bile was drain from her ENBD tube. A new nebulous high-density shadow in cholecyst was observed by enhanced abdomen/pelvis CT, which revealed active hemorrhage (Panel E). This patient underwent an emergency operation. Intraoperatively, there was necrosis and perforation on the gallbladder wall, multiple gallstones, clot and blood in lumen of gallbladder.

\section{Acknowledgments}

We thank numerous colleagues from Sir Run Run Shaw Hospital for their useful case data which have greatly improved the manuscript.

Funding: None. 


\section{Footnote}

Provenance and Peer Review: This article is a standard submission to the editorial office, Hepatobiliary Surgery and Nutrition. The article has been sent for external peer review.

Conflicts of Interest: Both authors have completed the ICMJE uniform disclosure form (available at https://hbsn. amegroups.com/article/view/10.21037/hbsn-20-737/coif). The authors have no conflicts of interest to declare.

Ethical Statement: The authors are accountable for all aspects of the work in ensuring that questions related to the accuracy or integrity of any part of the work are appropriately investigated and resolved. Written informed consent was obtained from the patient for publication of this manuscript and any accompanying images.

Open Access Statement: This is an Open Access article distributed in accordance with the Creative Commons Attribution-NonCommercial-NoDerivs 4.0 International License (CC BY-NC-ND 4.0), which permits the noncommercial replication and distribution of the article with the strict proviso that no changes or edits are made and the original work is properly cited (including links to both the formal publication through the relevant DOI and the license). See: https://creativecommons.org/licenses/by-nc-nd/4.0/.
Cite this article as: Chen $\mathrm{X}, \mathrm{Yu} \mathrm{L}$. A haemorrhagic cholecystitis presenting as obstructive jaundice. HepatoBiliary Surg Nutr 2021;10(2):299-300. doi: 10.21037/hbsn-20-737 